\title{
Preparation and Spectroscopic Studies of New Transition Metal Complexes of 1-(2, 2-Dicyclohexylethyl)-3-(1, 5-Dimethyl-3-Oxo-2-Phenyl-2,3- Dihydro-1H-pyrazol-4-ylimino) Indolin-2-One
}

\author{
Abbas Ali Salih Al-Hamdani, Amal S. Sadiq and Tamador A. Mahmood \\ Department of Chemistry, College of Science for Women, University of Baghdad, Baghdad-Iraq. \\ E-mail: Abbas_alhamadani@yahoo.co.uk.
}

\begin{abstract}
New tridentate ligand 1-(2, 2-dicyclohexylethyl)-3-(1, 5-dimethyl-3-oxo-2-phenyl-2,3-dihydro1H-pyrazol-4-ylimino)indolin-2-one (L) was synthesized from the reaction of 3-(1,5-dimethyl-3oxo-2-phenyl-2,3-dihydro-1H-pyrazol-4-ylimino)indolin-2-one and dicyclohexyl amine. Monomeric complexes of this ligand, of general formulae $\left[\mathrm{VO}^{\mathrm{II}}(\mathrm{L})\left(\mathrm{SO}_{4}\right)\right],\left[\mathrm{M}^{\mathrm{III}}\left(\mathrm{L}_{)} \mathrm{Cl}_{3}\right]\right.$ with $\mathrm{M}=\mathrm{Cr}{ }^{\mathrm{III}}$ and $\mathrm{Fe}^{\mathrm{III}}$, and $\left[\mathrm{M}^{\mathrm{II}}(\mathrm{L}) \mathrm{Cl}\right]$ Clwith $\left(\mathrm{M}=\mathrm{Mn}^{\mathrm{II}}\right.$ and $\left.\mathrm{Co}^{\mathrm{II}}\right)$ are reported. The mode of bonding and overall geometry of the complexes were determined through FT-IR, UV-Vis, and mass spectral studies, magnetic moment measurements, elemental analysis, metal content, chloride containing and molar conductance. These studies revealed octahedral geometries for the $\mathrm{Fe}^{\mathrm{III}}, \mathrm{Cr}^{\mathrm{III}}$ complexes, square pyramidal for $\mathrm{VO}^{\text {(II) }}$ complex and tetrahedral for the $\mathrm{Mn}^{\mathrm{II}}$ and $\mathrm{Co}^{\mathrm{II}}$ complexes. The study of complexes formation via molar ratio and job method in DMF solution has been investigated and results were consistent to those found in the solid complexes with a ratio of (M:L) as (1:1). Hyper Chem-8 program has been used to predict structural geometries of compounds in gas phase the heat of formation $\left(\Delta \mathrm{H}_{f}{ }^{\circ}\right)$, binding energy $\left(\Delta \mathrm{E}_{\mathrm{b}}\right)$, total energy, electronic energy and dipole moment at $298^{\circ} \mathrm{k}$.
\end{abstract}

Keywords: Tridentate ligand, dicyclohexyl amine and mannch Schiff base complexes.

\section{Introduction}

Schiff bases compounds containing azomethine group $(-\mathrm{C}=\mathrm{N}-)$ formed by condensation of primary amine and carbonyl compounds under acid or base catalysis or with heat [1], when aliphatic aldehydes are reaction relatively unstable and readily polymerizable while those of aromatic aldehydes, having an effective conjugation system are more stable [2]. Metal complex with Schiff bases are important class of ligands due to their synthetic flexibility, selectivity and sensitivity towards the central metal atom, structural similarities with natural biological substances, and also, due to presence of azomethine group which imports in elucidating the mechanism of transformation and racemisation reaction in biological system [3] also have been studied for their application in clinical, analytical and pharmacological areas [4]. Isatin as known (1H-indole-2,3-dione) possess both amide and keto carbonyl. The C-3 carbonyl group of isatin is strongly electrophilic and it readily undergoes condensation and addition reaction [5]. And through $\mathrm{NH}$ group compounds of the isatin series are capable of entering into $\mathrm{N}$ alkylation, $\mathrm{N}$-acylation and into the Mannich and Michael reaction [6]. Isatin Schiff bases are significant in therapeutic and pharmaceutical compounds in the field [7].

\section{Experimental}

The reagents were commercially available and used without further purification. Solvents were distilled from appropriate drying agents immediately prior to use. Elemental analyses $(\mathrm{C}, \mathrm{H}$ and $\mathrm{N}$ ) were performed using a PerkinElmer CHN 2400 elemental analyzer. The content of metal ions was calculated gravimetrically as metal oxides. Molar conductance measurements of the ligand and its complexes with $\left(10^{-3} \mathrm{M}\right)$ in DMSO were carried out using Jenway 4010 conductivity meter. Magnetic measurements were carried out on a Sherwood Scientific magnetic balance using the Gouy method. Electron impact $(70 \mathrm{eV})$ mass spectra were recorded on a Finnegan-MAT model 8430 LC-MS-DS spectrometer. The UV-Vis spectra were obtained in DMF solution $\left(10^{-3} \mathrm{M}\right)$ for the ligand and its metal complexes with a Jenway 
6405 spectrophotometer using $1 \mathrm{~cm}$ quartz cell, in the range $200-900 \mathrm{~nm}$. IR spectra (4000-400 $\mathrm{cm}^{-1}$ ) were recorded as $\mathrm{KBr}$ pellets on a Bruker FT-IR spectrophotometer.

Preparation of ligand: 1- $(2,2$-dicyclo hexylethyl)-3-(1,5-dimethyl-3-oxo-2-phenyl 2,3-dihydro-1H-pyrazol-4-ylimino) indolin-2one

a- Preparation of 3-(1,5-dimethyl-3-oxo-2phenyl-2,3-dihydro-1H-pyrazol-4-ylimino) indolin-2-one.

Equimolar $(0.01 \mathrm{~mol})$ quantity of indoline2,3-dione and 4-Aminoantipyrine were dissolved in sufficient amount of ethanol and refluxed for $3 \mathrm{hrs}$ in presence of glacial acetic acid. After standing for approximately $24 \mathrm{hrs}$. at room temperature, the products were separated byfiltration, dried under vacuum and recrystallized from war methanol.

\section{b- Preparation of 1-(2,2-dicyclohexyl ethyl)-} 3-(1,5-dimethyl-3-oxo-2-phenyl-2,3-dihydro1H-pyrazol-4-ylimino)indolin-2-one.

Equimolar quantity of dicyclohexyl amine $(0.01 \mathrm{~mol})$ in $25 \mathrm{ml}$ of ethanol was added to the solution containing Schiff bases and formaldehyde $(37 \% \mathrm{v} / \mathrm{v})$. The reaction mixture was stirred for $2 \mathrm{hrs}$ atroom temperature and heating for $3 \mathrm{hrs}$ followed kept under refrigeration for $24 \mathrm{hrs}$. The products were separated by suction filtration, dried under vacuum and recrystallized from ethanol. The molecular formula, molecularweight, melting point, yield and elemental analysis are shown in Table (1).

\section{Preparation of Complexes}

The preparation of all complexes is essentially the same and so a generic description will be presented. To a solution of (L) (1mmole) in ethanol was added slowly to a solution of metal salt $\left(\mathrm{VOSO}_{4} \cdot \mathrm{H}_{2} \mathrm{O}, \mathrm{CrCl}_{3}\right.$. $6 \mathrm{H}_{2} \mathrm{O}, \quad \mathrm{MnCl}_{2}$. $\quad 4 \mathrm{H}_{2} \mathrm{O}, \quad \mathrm{FeCl}_{3} \cdot 6 \mathrm{H}_{2} \mathrm{O}$, and $\mathrm{CoCl}_{2} \cdot 6 \mathrm{H}_{2} \mathrm{O}$ ) in (ethanol and water) ratio (1:1) with stirring the mixture was refluxed for (4hrs). The solid was collected by filtration, recrystallized from methanol and dried at room temperature. Elemental analysis data, color and yield for the complexes are given in Table (1).

\section{Results and discussion}

The new (NO) and (ONO) dentate ligand L was obtained in good yield by the reaction of 3-(1,5-dimethyl-3-oxo-2-phenyl-2,3-dihydro1H-pyrazol-4-ylimino)indolin-2-one and dicyclo hexylamine, Scheme 1. In general the ligand was characterized by elemental analysis Table (1), IR Table (2), UV-Vis Table (3), mass spectroscopy. Monomeric complexes of the ligand with $\mathrm{Mn}^{\mathrm{II}}, \mathrm{Co}^{\mathrm{II}}, \mathrm{VO}^{\mathrm{II}}, \mathrm{Fe}^{\mathrm{III}}$ and $\mathrm{Cr}^{\mathrm{III}}$ were synthesized by heating $(1 \mathrm{mmol})$ of each ligand with $(1 \mathrm{mmol})$ of metal salt, using ethanolic. However, in ethanolic, deprotonation of the ligand occur facilitating the formation of the complexes $\left[\mathrm{VO}^{\mathrm{II}}(\mathrm{L})\left(\mathrm{SO}_{4}\right)\right],\left[\mathrm{M}^{\mathrm{III}}(\mathrm{L}) \mathrm{Cl}_{3}\right]$ with $\mathrm{M}^{\mathrm{III}}=\mathrm{Cr}$ and $\mathrm{Fe}$, and $\left[\mathrm{M}^{\mathrm{II}}(\mathrm{L}) \mathrm{Cl}\right] \mathrm{Cl}\left(\mathrm{M}^{\mathrm{II}}=\mathrm{Mn}\right.$ and $\left.\mathrm{Co}\right)$ are reported, scheme (2). The complexes are airstable solids, soluble in DMF and DMSO, sparingly soluble in $\mathrm{MeOH}, \mathrm{CHCl}_{3}, \mathrm{CH}_{2} \mathrm{Cl}_{2}$ and not soluble in other common organic solvents. The analytical data Tables (1) agree well with the suggested formulae. 
<smiles>O=C1Nc2ccccc2C1=O</smiles>

indoline-2,3-dione<smiles>CN(C1CCCCC1)C1CCCCC1</smiles>
4-amino-1,5-dimethyl-2-phenyl-1 $H$-pyrazol-3(2H)-one<smiles>CC(=O)OCC(C)C(C)C</smiles>

(E)<smiles>N=C1C(=O)Nc2ccccc21</smiles><smiles>Cc1c(I)c(=O)n(-c2ccccc2)n1C</smiles>

3-(1,5-dimethyl-3-oxo-2-phenyl-2,3-dihydr o- $1 H$-pyrazol-4-y limino)indolin-2-one (Schiff base)<smiles>C1CCC(NC2CCCCC2)CC1</smiles><smiles>Cc1c(/N=C2\C(=O)N(C)C3=C2C=CCC3)c(=O)n(-c2ccccc2)n1C</smiles>

dicyclohexylamine

(Z)-1-((dicyclohexylamino)methyl)-3-(1,5-dimethyl-3-oxo-2phenyl-2,3-dihydro-1 $H$-pyrazol-4-ylimino)indolin-2-one (L)

\section{Scheme (1) Synthesis route of the ligand.}

Table (1)

Analytical and physical data of the ligand and its complexes.

\begin{tabular}{|c|c|c|c|c|c|c|c|c|c|}
\hline \multirow{2}{*}{ Compounds } & \multirow{2}{*}{$\begin{array}{c}\text { Formula } \\
\text { M. wt }\end{array}$} & \multirow{2}{*}{ Color } & \multirow{2}{*}{$\begin{array}{l}\text { M. P. } \\
\quad{ }^{o} \mathrm{C}\end{array}$} & \multirow{2}{*}{$\begin{array}{l}\text { Yield } \\
\%\end{array}$} & \multicolumn{5}{|c|}{ Elemental analysis, found (Calc.)\% } \\
\hline & & & & & $\bar{C}$ & $\boldsymbol{H}$ & $N$ & $M$ & $C l$ \\
\hline $\mathrm{L}$ & $\begin{array}{c}\mathrm{C}_{32} \mathrm{H}_{39} \mathrm{~N}_{5} \mathrm{O}_{2} \\
525.3\end{array}$ & $\begin{array}{l}\text { Orange } \\
\text { red }\end{array}$ & $156-158$ & 87 & $\begin{array}{c}73.16 \\
(74.16)\end{array}$ & $\begin{array}{c}7.42 \\
(7.17)\end{array}$ & $\begin{array}{c}13.32 \\
(12.40)\end{array}$ & & \\
\hline $\mathrm{CoL}$ & $\begin{array}{c}\mathrm{C}_{32} \mathrm{H}_{39} \mathrm{~N}_{5} \mathrm{O}_{2} \mathrm{Cl}_{2} \mathrm{Co} \\
655.13\end{array}$ & Violate & $265 d$ & 74 & $\begin{array}{c}58.66 \\
(60.06)\end{array}$ & $\begin{array}{c}5.95 \\
(5.53)\end{array}$ & $\begin{array}{c}10.68 \\
(10.04)\end{array}$ & $\begin{array}{c}8.99 \\
(10.00)\end{array}$ & $\begin{array}{c}10.82 \\
(10.98)\end{array}$ \\
\hline $\mathrm{MnL}$ & $\begin{array}{c}\mathrm{C}_{32} \mathrm{H}_{39} \mathrm{~N}_{5} \mathrm{O}_{2} \mathrm{Cl}_{2} \mathrm{Mn} \\
651.13\end{array}$ & $\begin{array}{l}\text { Yellow } \\
\text { greenish }\end{array}$ & $266 \mathrm{~d}$ & 75 & $\begin{array}{c}59.02 \\
(58.82)\end{array}$ & $\begin{array}{c}5.98 \\
(5.59)\end{array}$ & $\begin{array}{l}10.75 \\
(8.14)\end{array}$ & $\begin{array}{c}8.43 \\
(9.00)\end{array}$ & $\begin{array}{l}10.88 \\
(9.98)\end{array}$ \\
\hline FeL & $\begin{array}{c}\mathrm{C}_{32} \mathrm{H}_{39} \mathrm{~N}_{5} \mathrm{O}_{2} \mathrm{Cl}_{3} \mathrm{Fe} \\
687.64\end{array}$ & $\begin{array}{l}\text { Yellow } \\
\text { greenish }\end{array}$ & $222 d$ & 71 & $\begin{array}{c}55.88 \\
(58.82)\end{array}$ & $\begin{array}{c}5.71 \\
(5.59)\end{array}$ & $\begin{array}{l}10.18 \\
(8.84)\end{array}$ & $\begin{array}{c}8.12 \\
(9.00)\end{array}$ & $\begin{array}{l}15.46 \\
(9.98)\end{array}$ \\
\hline $\mathrm{CrL}$ & $\begin{array}{c}\mathrm{C}_{32} \mathrm{H}_{39} \mathrm{~N}_{5} \mathrm{O}_{2} \mathrm{Cl}_{3} \mathrm{Cr} \\
683.65\end{array}$ & $\begin{array}{l}\text { Yellow } \\
\text { greenish }\end{array}$ & $278 \mathrm{~d}$ & 82 & $\begin{array}{c}56.21 \\
(55.82)\end{array}$ & $\begin{array}{c}5.70 \\
(5.59)\end{array}$ & $\begin{array}{l}10.24 \\
(8.94)\end{array}$ & $\begin{array}{c}7.60 \\
(9.00)\end{array}$ & $\begin{array}{c}15.55 \\
(14.98)\end{array}$ \\
\hline VOL & $\begin{array}{c}\mathrm{C}_{32} \mathrm{H}_{39} \mathrm{~N}_{5} \mathrm{O}_{7} \mathrm{SV} \\
688.31\end{array}$ & $\begin{array}{l}\text { Yellow } \\
\text { greenish }\end{array}$ & $280 \mathrm{~d}$ & 89 & $\begin{array}{c}55.83 \\
(56.82)\end{array}$ & $\begin{array}{c}5.66 \\
(5.59)\end{array}$ & $\begin{array}{l}10.17 \\
(8.94)\end{array}$ & $\begin{array}{c}7.40 \\
(9.00)\end{array}$ & $\begin{array}{c}\mathrm{S}=4.66 \\
(4.98)\end{array}$ \\
\hline
\end{tabular}

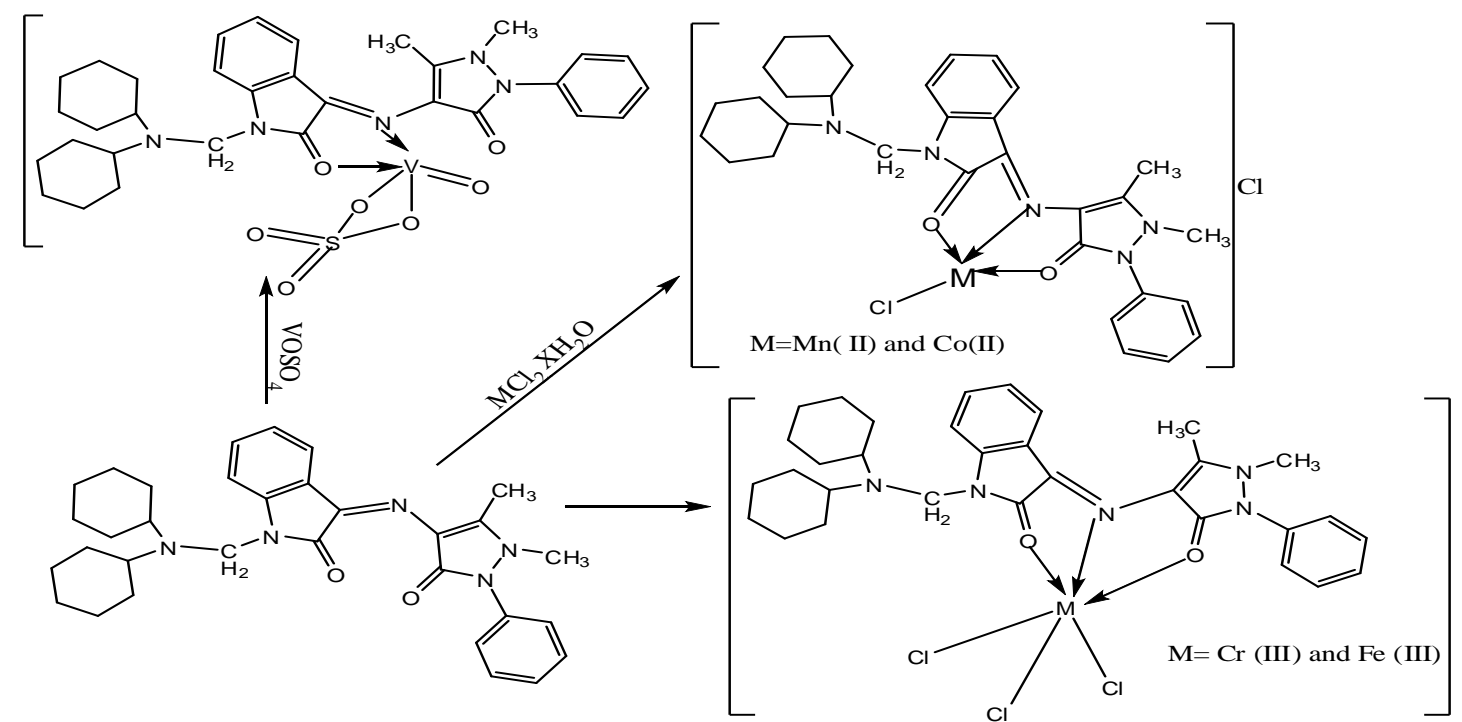

Scheme (2) Proposed structures of metal complexes. 


\section{IR spectra}

The IR spectra bands of the ligand (L) and its complexes were characterized at 31513089, 2966-2897, 1724-1651 and $1620 \mathrm{~cm}^{-1}$ due to the $v(\mathrm{CH})$ aromatic, $v(\mathrm{CH})$ aliphatic, $v(\mathrm{C}=\mathrm{O})$, and $v(\mathrm{C}=\mathrm{N})$ functional groups, respectively, for the ligand [9]. The IR spectraof the complexes exhibited ligand bands with the appropriate shifts due complexes formation [10]. Moreover, the $v(\mathrm{C}=\mathrm{O}), v(\mathrm{C}=\mathrm{N})$, bands of the ligand were observed at $(1724,1651) \mathrm{cm}^{-1}$ and $1620 \mathrm{~cm}^{-1}$ and these bands were shifted to the lower frequencies by $(24-11,27-11)$ and (42-9) $\mathrm{cm}^{-1}$ respectively in the spectra of the complexes. This indicates that the ligand was coordinated with the metal ions through the $\mathrm{O}$, O carbonyl groups and $\mathrm{N}$ azomethine group atoms, but these shifts confirm the coordination of the ligand via the nitrogen of azomethine and the oxygen of carbonyl group to vanadyl ions. At lower frequency the complexes exhibited new bands around (588-508), and (450-413) $\mathrm{cm}^{-1}$ assigned to the $v(\mathrm{M}-\mathrm{N})$ and $v(\mathrm{M}-\mathrm{O})$, respectively $[10,11]$.

Table (2)

FTIR spectral data (wave number $v^{-}$) $\mathrm{cm}^{-1}$ for the ligand and its complexes.

\begin{tabular}{|c|c|c|c|c|c|c|c|}
\hline Compound & C-H arom & C-H alip & $C=O$ & $C=N$ & $M-N$ & $M-O$ & \\
\hline $\mathrm{L}$ & $\begin{array}{l}3151 \\
3089\end{array}$ & $\begin{array}{l}2966 \\
2897\end{array}$ & $\begin{array}{l}1724 \\
1651\end{array}$ & 1620 & - & - & \\
\hline $\mathrm{CoL}$ & $\begin{array}{l}3099 \\
3029 \\
\end{array}$ & $\begin{array}{l}2956 \\
2897 \\
\end{array}$ & $\begin{array}{l}1700 \\
1636 \\
\end{array}$ & 1578 & $\begin{array}{l}570 \\
508 \\
\end{array}$ & 440 & \\
\hline $\mathrm{MnL}$ & $\begin{array}{l}3111 \\
3035 \\
\end{array}$ & 2939 & $\begin{array}{l}1702 \\
1627 \\
\end{array}$ & 1582 & 588 & $\begin{array}{l}450 \\
433 \\
\end{array}$ & \\
\hline $\mathrm{FeL}$ & $\begin{array}{l}3118 \\
3065 \\
\end{array}$ & $\begin{array}{l}2954 \\
2864 \\
\end{array}$ & $\begin{array}{l}1713 \\
1624 \\
\end{array}$ & 1597 & 554 & $\begin{array}{l}425 \\
413 \\
\end{array}$ & \\
\hline $\mathrm{CrL}$ & $\begin{array}{l}3111 \\
3078 \\
\end{array}$ & $\begin{array}{l}2987 \\
2894 \\
\end{array}$ & $\begin{array}{l}1711 \\
1640 \\
\end{array}$ & 1607 & 534 & 442 & \\
\hline VOL & $\begin{array}{l}3100 \\
3042 \\
\end{array}$ & $\begin{array}{l}2946 \\
2853 \\
\end{array}$ & 1629 & 1611 & 555 & $\begin{array}{l}432 \\
449 \\
\end{array}$ & $\begin{array}{c}v(\mathrm{~V}=\mathrm{O})=936 \\
v\left(\mathrm{SO}_{4}\right)=978,951 \\
\end{array}$ \\
\hline
\end{tabular}

arom $=$ aromatic and alip $=$ aliphatic

Electronic spectral, magnetic moments and conductivity measure ements

The electronic spectrum of the ligand exhibits intense absorption at $(282,330)$ and $348 \mathrm{~nm}$ attributed to $\pi \rightarrow \pi^{*}$ and $\mathrm{n} \rightarrow \pi^{*}$, respectively. The electronic spectrum of $\mathrm{Co}(\mathrm{II})$ complex showed three broad peaks at 27397,15873 and $13986 \mathrm{~cm}^{-1}$ assigned to ${ }^{4} \mathrm{~A}_{2} \mathrm{~F} \longrightarrow{ }^{4} \mathrm{~T}_{1(\mathrm{P})},{ }^{4} \mathrm{~A}_{2} \mathrm{~F} \rightarrow{ }^{4} \mathrm{~T}_{1(\mathrm{~F})}$ and ${ }^{4} \mathrm{~A}_{2} \mathrm{~F} \longrightarrow{ }^{4} \mathrm{~T}_{2(\mathrm{~F})}$ and the electronic spectrum of $\mathrm{Mn}$ (II) complex showed two broad peaks at 28490 and $27322 \mathrm{~cm}^{-1}$ assigned to ${ }^{6} \mathrm{~A}_{1} \rightarrow{ }^{4} \mathrm{E}_{(\mathrm{D})}$ and ${ }^{6} \mathrm{~A}_{1} \rightarrow{ }^{4} \mathrm{~T}_{2(\mathrm{D})}$ respectively. The $\mathrm{Fe}^{(\mathrm{III})}$ complex exhibited peak at $21739 \mathrm{~cm}^{-1}$ which assign to ${ }^{5} \mathrm{~T}_{2} \mathrm{~g} \rightarrow{ }^{5} \mathrm{Eg}$ (D) transition, suggesting an octahedral geometry around the $\mathrm{Fe}^{(\mathrm{III})}$ ion $[13,14]$. The spectra of the $\mathrm{Cr}^{(\mathrm{III})}$ complex of together with the Mett value Table (3) suggest octahedral geometry around for complex. The spectrum of $\mathrm{VO}^{\text {(II) }}$ complex gave one band at $15576 \mathrm{~cm}^{-1}$ assigned to ${ }^{2} \mathrm{~B}_{2} \rightarrow{ }^{2} \mathrm{~A}_{1}$ and ${ }^{2} \mathrm{~B}_{2} \rightarrow{ }^{2} \mathrm{E}$ transition, respectively suggesting a square pyramidal geometry [15-17]. The magnetic moment value $3.54,4.45$ B.M. of $\mathrm{Co}(\mathrm{II})$, $\mathrm{Mn}$ (II) complexes respectively are typical for tetrahedral geometry [13]. The magnetic moment value at this complex consistent with octahedral geometry structure. The molar conductivity value of the complexes were consistent with non electrolytes for $\mathrm{VO}^{(\mathrm{II})}$, $\mathrm{Cr}^{(\mathrm{III})}$ and $\mathrm{Fe}^{(\mathrm{III})}$ complexes and 1:1 electrolytes for $\mathrm{Mn}^{(\mathrm{II})}, \mathrm{Co}^{(\mathrm{II})}$ complexes. See the scheme (1) the preparation of the ligand and scheme (2) for its complexes. 
Table (3)

Electronic data magnetic moment and molar conductivity for the metal complexes.

\begin{tabular}{|c|c|c|c|c|c|c|}
\hline Complexes & $\begin{array}{c}\text { Molar } \\
\text { Conductive } \\
\text { cm }^{2} \text { s mole } \\
\text { in DMSO } \\
\end{array}$ & $\begin{array}{c}\mu_{\text {eff }} \\
M . B .\end{array}$ & $\begin{array}{c}\lambda_{\max } \\
n m\end{array}$ & $\begin{array}{c}v^{\prime} \\
\mathrm{cm}^{-1}\end{array}$ & $\begin{array}{c}\varepsilon \max \\
\mathrm{Lmol}^{-1} \mathrm{~cm}^{-1}\end{array}$ & Assignment \\
\hline $\begin{array}{c}\text { CoL } \\
\text { Tetrahedral }\end{array}$ & 77 & 3.54 & $\begin{array}{l}351 \\
365 \\
630 \\
715 \\
\end{array}$ & $\begin{array}{l}28490 \\
27397 \\
15873 \\
13986 \\
\end{array}$ & $\begin{array}{c}896 \\
966 \\
16 \\
22 \\
\end{array}$ & $\begin{array}{c}\mathrm{C} . \mathrm{T} \\
{ }^{4} \mathrm{~A}_{2 \mathrm{~F}} \rightarrow{ }^{4} \mathrm{~T}_{1(\mathrm{P})} \\
{ }^{4} \mathrm{~A}_{2 \mathrm{~F}} \rightarrow{ }^{4} \mathrm{~T}_{1(\mathrm{~F})} \\
{ }^{4} \mathrm{~A}_{2 \mathrm{~F}} \longrightarrow{ }^{4} \mathrm{~T}_{2(\mathrm{~F})}\end{array}$ \\
\hline $\begin{array}{c}\text { MnL } \\
\text { Tetrahedral }\end{array}$ & 59 & 4.45 & $\begin{array}{l}296 \\
345 \\
351 \\
366 \\
\end{array}$ & $\begin{array}{l}33783 \\
28985 \\
28490 \\
27322 \\
\end{array}$ & $\begin{array}{c}1235 \\
2500 \\
882 \\
946 \\
\end{array}$ & $\begin{array}{c}\text { (C.T) } \\
(\mathrm{C} . \mathrm{T}) \\
{ }^{6} \mathrm{~A}_{1} \rightarrow{ }^{4} \mathrm{E}_{(\mathrm{D})} \\
{ }^{6} \mathrm{~A}_{1} \rightarrow{ }^{4} \mathrm{~T}_{2(\mathrm{D})} \\
\end{array}$ \\
\hline $\begin{array}{c}\text { VOL } \\
\text { Square } \\
\text { Pyramidal } \\
\end{array}$ & 19 & 1.77 & $\begin{array}{l}370 \\
642\end{array}$ & $\begin{array}{l}27027 \\
15576\end{array}$ & $\begin{array}{c}1157 \\
43\end{array}$ & $\begin{array}{c}\text { C.T } \\
{ }^{2} \mathrm{~B}_{2} \rightarrow{ }^{2} \mathrm{~A}_{1} \\
{ }^{2} \mathrm{~B}_{2} \rightarrow{ }^{2} \mathrm{E} \\
\end{array}$ \\
\hline $\begin{array}{c}\text { CrL } \\
\text { Octahedral }\end{array}$ & 88 & 3.13 & $\begin{array}{l}357 \\
425 \\
510 \\
\end{array}$ & $\begin{array}{r}28011 \\
23529 \\
19607 \\
\end{array}$ & $\begin{array}{l}891 \\
560 \\
\\
68 \\
\end{array}$ & $\begin{array}{c}\text { C.T } \\
{ }^{4} \mathrm{~A}_{2 \mathrm{~g}(\mathrm{~F})} \rightarrow \mathrm{T}_{1 \mathrm{P}} \\
{ }^{4} \mathrm{~A}_{2 \mathrm{~g}(\mathrm{~F})} \rightarrow \mathrm{T}_{1 \mathrm{~F}} \\
{ }^{4} \mathrm{~A}_{2 \mathrm{~g}(\mathrm{~F})} \rightarrow \mathrm{T}_{2 \mathrm{~F}}\end{array}$ \\
\hline $\begin{array}{c}\text { FeL } \\
\text { Octahedral }\end{array}$ & 83 & 5.77 & $\begin{array}{l}371 \\
460 \\
\end{array}$ & $\begin{array}{l}26954 \\
21739 \\
\end{array}$ & $\begin{array}{c}1171 \\
187 \\
\end{array}$ & $\begin{array}{c}\text { C. T } \\
{ }^{5} \mathrm{~T}_{2} \mathrm{~g} \rightarrow{ }^{5} \mathrm{Eg}(\mathrm{D}) \\
\end{array}$ \\
\hline
\end{tabular}

\section{Mass spectrum}

The electron impact spectrum of ligand (L) confirms the probable formula by showing a peak at $(525.4 \mathrm{~m} / \mathrm{z})$ cores bonding to mannch Schiff base moiety $\left[\left(\mathrm{C}_{32} \mathrm{H}_{39} \mathrm{~N}_{5} \mathrm{O}_{2}\right)\right.$ calculated atomic mass 525.4]. The series of peaks at $205 \mathrm{~m} / \mathrm{z}$ is attributed to $\left(\mathrm{C}_{11} \mathrm{H}_{15} \mathrm{~N}_{3} \mathrm{O}\right), 204 \mathrm{~m} / \mathrm{z}$ is attributed to $\left(\mathrm{C}_{11} \mathrm{H}_{14} \mathrm{~N}_{3} \mathrm{O}\right), 194 \mathrm{~m} / \mathrm{z}$ is attributed to $\left(\mathrm{C}_{13} \mathrm{H}_{24} \mathrm{~N}\right), 75 \mathrm{~m} / \mathrm{z}$ is attributed to $\left(\mathrm{C}_{3} \mathrm{H}_{9} \mathrm{NO}\right)$ and $36 \mathrm{~m} / \mathrm{z}$ is attributed to $\left(\mathrm{H}_{6} \mathrm{NO}\right)$, and the fragmentation pattern for complexes confirms the probable formula by showing a peak at $(655.4 \mathrm{~m} / \mathrm{z})$ cores bonding to $\mathrm{Co}^{\mathrm{II}}$ complex moiety $\left[\left(\mathrm{C}_{32} \mathrm{H}_{39} \mathrm{~N}_{5} \mathrm{O}_{2} \mathrm{CoCl}_{2}\right)\right.$ calculated atomic mass 655.4]. The series of peak at $616 \mathrm{~m} / \mathrm{z}$ is attributed to $\left(\mathrm{C}_{32} \mathrm{H}_{35} \mathrm{~N}_{5} \mathrm{O}_{2} \mathrm{CoCl}\right), 430 \mathrm{~m} / \mathrm{z}$ is attributed to $\left(\mathrm{C}_{21} \mathrm{H}_{17} \mathrm{~N}_{5} \mathrm{O}_{2} \mathrm{Co}\right), 429 \mathrm{~m} / \mathrm{z}$ is attributed to $\left(\mathrm{C}_{21} \mathrm{H}_{16} \mathrm{~N}_{5} \mathrm{O}_{2} \mathrm{Co}\right), 205 \mathrm{~m} / \mathrm{z}$ is attributed to $\left(\mathrm{C}_{11} \mathrm{H}_{15} \mathrm{~N}_{3} \mathrm{O}\right)$ and $204 \mathrm{~m} / \mathrm{z}$ is attributed to $\left(\mathrm{C}_{11} \mathrm{H}_{14} \mathrm{~N}_{3} \mathrm{O}\right)$. And $\mathrm{Mn}^{\mathrm{II}}$ complex moiety $\left[\left(\mathrm{C}_{32} \mathrm{H}_{39} \mathrm{~N}_{5} \mathrm{O}_{2} \mathrm{MnCl}_{2}\right)\right.$ calculated atomic mass $651.5]$, the series of peaks at $614 \mathrm{~m} / \mathrm{z}$ is attributed to $\left(\mathrm{C}_{32} \mathrm{H}_{37} \mathrm{~N}_{5} \mathrm{O}_{2} \mathrm{MnCl}\right), 430 \mathrm{~m} / \mathrm{z}$ is attributed to $\left(\mathrm{C}_{18} \mathrm{H}_{21} \mathrm{~N}_{5} \mathrm{O}_{2} \mathrm{MnCl}\right), 429 \mathrm{~m} / \mathrm{z}$ is attributed to $\left(\mathrm{C}_{18} \mathrm{H}_{20} \mathrm{~N}_{5} \mathrm{O}_{2} \mathrm{ClMn}\right), 205 \mathrm{~m} / \mathrm{z}$ is attributed to $\left(\mathrm{C}_{11} \mathrm{H}_{15} \mathrm{~N}_{3} \mathrm{O}\right)$ and $204 \mathrm{~m} / \mathrm{z}$ is attributed to $\left(\mathrm{C}_{11} \mathrm{H}_{14} \mathrm{~N}_{3} \mathrm{O}\right)$.

\section{Theoretical study}

A theoretically probable structure of A metal complexes with ligand were calculated to search for the most probable model building stable structure, these shapes, show the calculated optima geometries for ligand. The results of PM3 method of calculation in gas phase for the binding energies and heat of formation of complexes are described in Table (4). The conformation structures and bond lengths of the ligand and its complexes showed in Fig.(1). 
Table (4)

Conformation energetic in $\left(K \mathrm{~J}^{\mathrm{M}} \mathrm{Mol}^{-1}\right)$ for the ligand and complexes.

\begin{tabular}{|c||c||c||c||c||c||}
\hline \hline Compounds & Binding Energy & $\begin{array}{c}\text { Heat of } \\
\text { Formation }\end{array}$ & $\begin{array}{c}\text { Electronic } \\
\text { Energy }\end{array}$ & $\begin{array}{c}\text { Dipole moment } \\
\text { (debyes) }\end{array}$ & Total Energy \\
\hline \hline $\mathrm{L}$ & -4087.8472761 & 2122.6407239 & -963880.021879 & 23.39 & -116619.300806 \\
\hline \hline $\mathrm{CoL}$ & -4326.4163316 & 2015.4616684 & -1169716.1185115 & 19.648 & -142058.723112 \\
\hline \hline $\mathrm{MnL}$ & -4157.8280108 & 2149.3499892 & -1135762.7660891 & 6.152 & -132846.9020078 \\
\hline \hline $\mathrm{FeL}$ & -4112.78009 & 1981.34446 & -1117854.1178 & 8.156 & -114221.76535 \\
\hline \hline $\mathrm{CrL}$ & -3998.176532 & 1652.11655 & -808754.11950 & 7.114 & -219901.1675 \\
\hline $\mathrm{VOL}$ & -3398.1997601 & 1763.5667 & -787154.458 & 9.875 & -29998.11537 \\
\hline
\end{tabular}

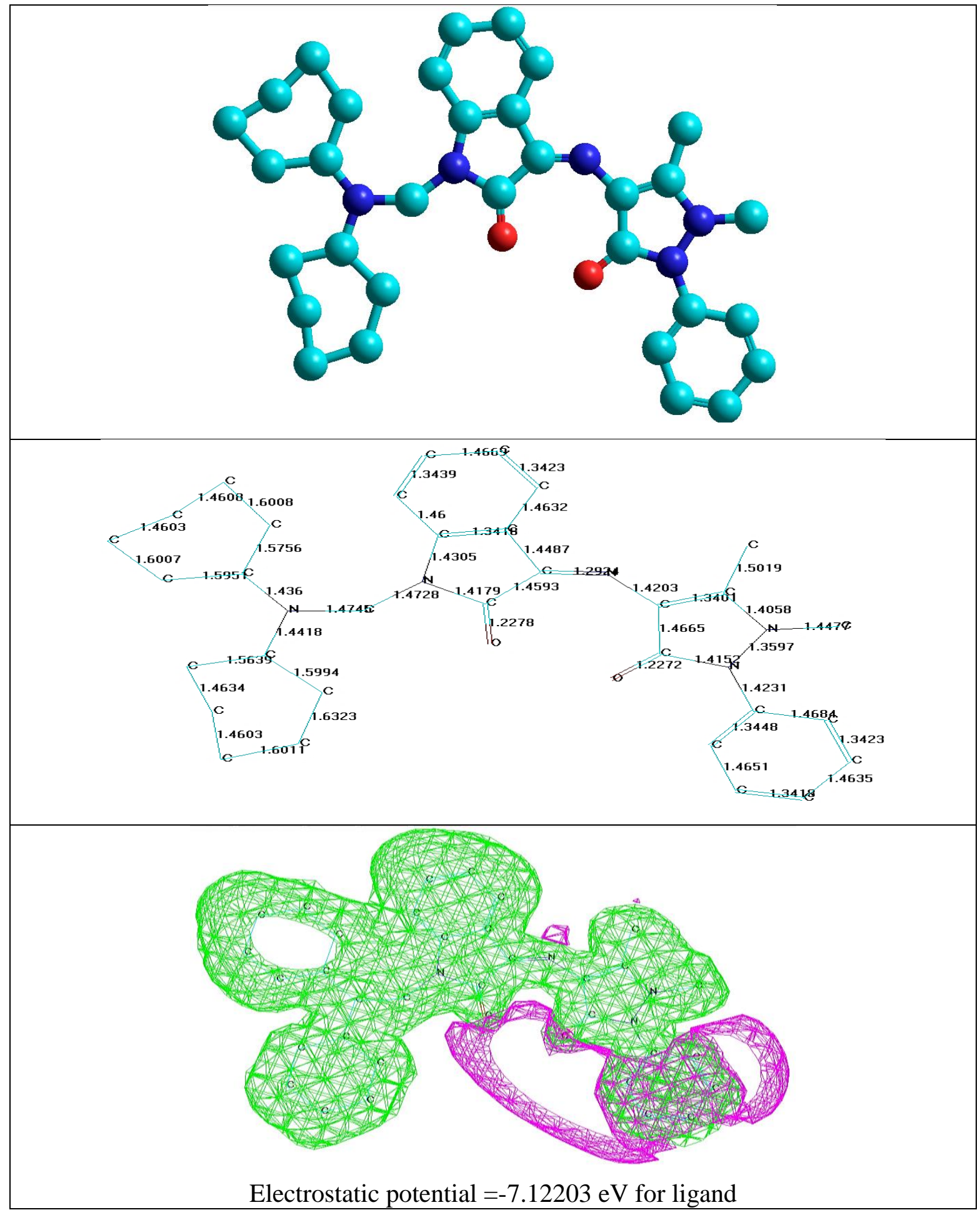




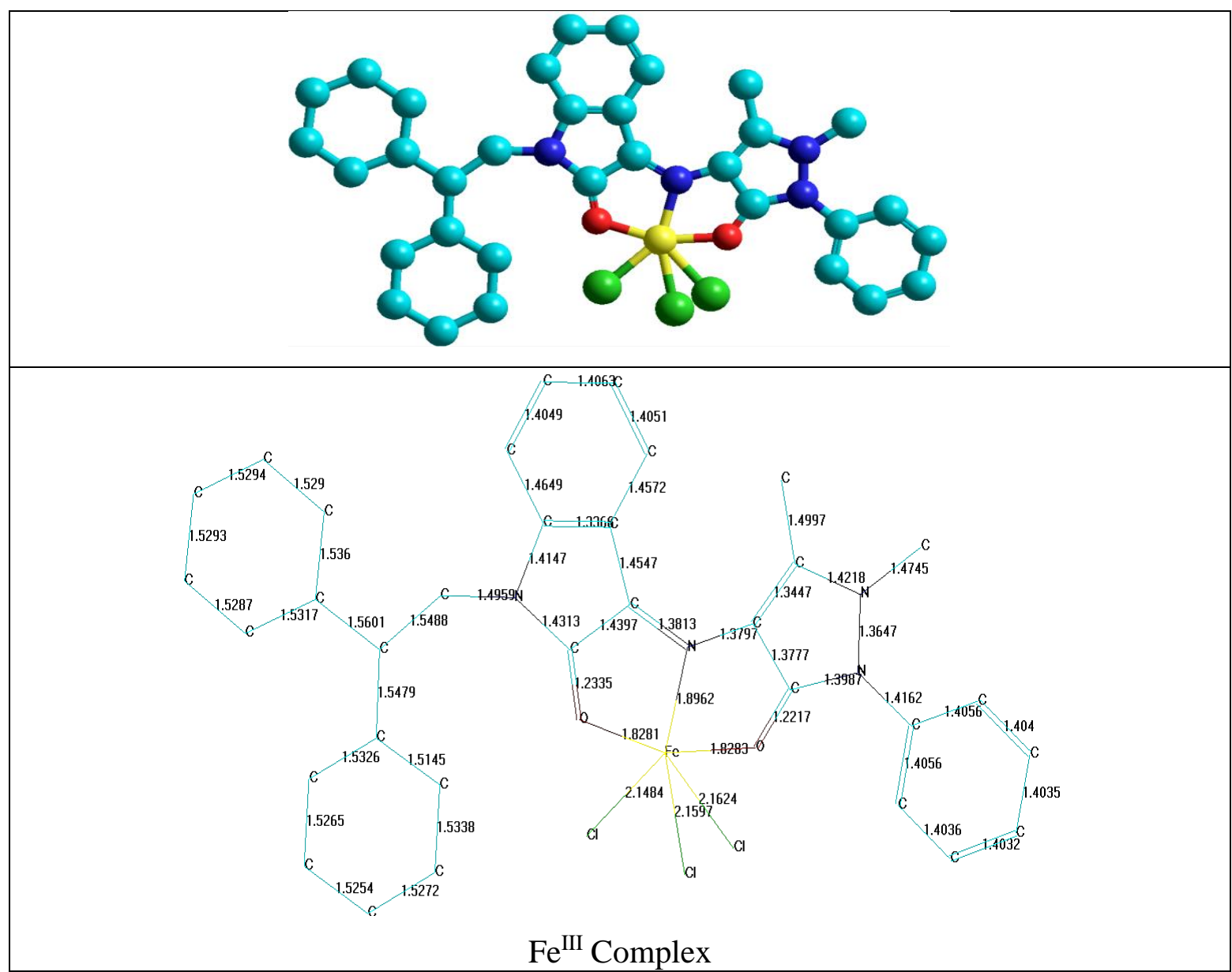

Fig.(1): conformation structures, bond length of ligand and Fe $e^{I I I}$ complex.

\section{Conclusion}

In this paper synthesis and characterization of new mannich Schiff bases ligand 1-(2, 2dicyclohexylethyl)-3-(1, 5-dimethyl-3-oxo-2phenyl-2,3-dihydro-1H-pyrazol-4-

ylimino)indolin-2-one (L) from reaction 3(1,5-dimethyl-3-oxo-2-phenyl-2,3-dihydro-

1H-pyrazol-4-ylimino) indolin-2-one (Schiff base) with dicyclohexyl amine and its preparation of complexes with the general formula $\left[\mathrm{VO}^{\mathrm{II}}(\mathrm{L})\left(\mathrm{SO}_{4}\right)\right], \quad\left[\mathrm{M}^{\mathrm{III}}(\mathrm{L}) \mathrm{Cl}_{3}\right]$ with $\mathrm{M}=\mathrm{Cr}^{\mathrm{III}}$ and $\mathrm{Fe}^{\mathrm{III}}$, and $\left[\mathrm{M}^{\mathrm{II}}(\mathrm{L}) \mathrm{Cl}\right] \mathrm{Cl}$ with $\left(\mathrm{M}=\mathrm{Mn}^{\mathrm{II}}\right.$ and $\left.\mathrm{Co}^{\mathrm{II}}\right)$ are reported. The molar conductivity of the complexes in DMSO solution was non-electrolyte for all complexes, but the $\mathrm{Co}^{\mathrm{II}}$ and $\mathrm{Mn}^{\mathrm{II}}$ complexes electrolyte (1:1), and the configurations were performed to coordinate the mannich Schiff base through the nitrogen and oxygen atoms. Therefore, from the presented results the complexes have tetrahedral for $\mathrm{Co}^{\mathrm{II}}$ and $\mathrm{Mn}^{\mathrm{II}}$ complexes , square pyramidal with $\mathrm{VO}^{\mathrm{II}}$ complex and octahedral geometry with $\mathrm{Fe}^{\mathrm{III}}$ and $\mathrm{Cr}^{\mathrm{III}}$ complexes configuration. Theoretically probable structures of metal complexes with mannich Schiff base have been calculated, these shapes shows the calculated optima geometries for $\mathrm{L}$ and its metal complexes.

\section{Acknowledgments}

Thanks are due to the College of Sciences of women, University of Baghdad.

\section{References}

[1] Sani, U., "Synthesis, Characterization and Antimicrobial Activity of Nickel (II) Complex with a Schiff base Derived from Salicyldehyde and Phenylhydrazine"; Centrepoint Journal, 17( 2):113-118; 2011.

[2] Arulmurugan1, S.; Helen, P. Kavitha1; and Venkatraman, B. R., "Biological Activities of Schiff base and its Complexes: A review"; ASAYA J. Chem., 3(3):385-410; 2010. 
[3] Al-Hassani, R. A.; Sinan, M. Mohamed and Abdullah, S. M., "Synthesis, characterization, photo degradation and biological study of Schiff base of Isatin derivative with $\mathrm{Zr}(\mathrm{IV}), \mathrm{Rh}(\mathrm{III})$ and $\mathrm{Pd}(\mathrm{II})$ Ions"; Peak J. Phys. Environ. Sci. Res., 1(6):95-105; 2013.

[4] Muna, A., "Coordination Behavior of N/O donor ligand with some transition metals"; Acta Chim. Pharm. Indica:, 3(2):127-134; 2013.

[5] Abdulghani, A. J.; and Ahmed, Z. Z., "Synthesis, Structure and Characterization of New Metal Complexes of Schiff Bases Derived from Isatin N-Benzylisatin and 4Aminoantipyrine"; Pakistan Journal of Chemistry., 1(3):100-113; 2011.

[6] AL- Bayati, Kh. A., "Synthesis and study of some new mannich bases derived from Isatin (1H-Indole -2,3- Dione) with Substituted Sulfonamides and Their Antimicrobial Activity"; Tikrit Journal of Pure Science, 17 (2):40-45; 2012.

[7] Ramadoss, G.; Andy, R.; and Athiappan, M., "Evaluation of DNA Binding, Cleavage, and Cytotoxic Activity of $\mathrm{Cu}(\mathrm{II})$, $\mathrm{Co}(\mathrm{II})$, and Ni(II) Schiff Base Complexes of 1-Phenylindoline-2,3-dione with Isonicotino hydrazide"; Bioino. Chem. and Appli., 1-12; 2014.

[8] Abbas, A. S. Al-Hamdani; "Metal complexes of multidentate Schiff baseazoligand: synthesis, characterization and biological activity"; Dirasat, Pure Sciences, 39 (1):61-72; 2013.

[9] Yousif, E.; Salih, N.; and Majeed, A. S., "Synthesis, characterization and preliminary in vitro antibacterial screening activity of metal complex derivatives of 2[(5-styryl-[1,3,4] thiadazol-2-ylimino)methyl]-phenol"; Journal of Taibah University for Science, 8:26-30; 2014.

[10] Abbas, A. S. Al-Hamdani; and Shayma, A. Sh., "Synthesis, characterization, structural studies and biological activity of a new Schiff base- azoligand and its complexation with selected metal ions"; Journal Oriental Chemistry., 27:835-845; 2011.
[11] Nakamoto, N.; "Infrared and Raman Spectra of Inorganic and Coordination Compounds"; John Wiley \& Sons, Inc., $6^{\text {th }}$ Ed., New Jersey; 2009.

[12] Abbas, A. S. Al-Hamdani; Balkhi, A. M.; and Falah, A., "Synthesis, Spectroscopic and biological activity Studies of AzoSchiff base and Metal Complexes derived from 5-Methyltryptamine"; Damascus University Journal for Basic Sci., 29(2):2141; 2013.

[13] Lever, A. B., "Inorganic electronic spectroscopy", Elsevier Amsterdam, 1984.

[14] Shayma, A. Sh.; Yang, F. and Abbas, A. S. Al-Hamdani., "Synthesis and Characterization of Mixed Ligand Complexes of 8-Hydroxyquinoline and ohydroxybenzylidene-1-phenyl-2,3-

dimethyl-4-amino-3-pyrazolin-5-on with $\mathrm{Fe}(\mathrm{II}), \mathrm{Co}(\mathrm{II}), \mathrm{Ni}(\mathrm{II})$ and $\mathrm{Cu}(\mathrm{II})$ ions"; European Journal. Scie. Resea., 33(4):702709; 2009.

[15] Abbas, A. S. Al-Hamdani., "Synthesis and Characterization of some new transition metal complexes with 2,5- di(4-amino phenazonyl) hexane"; Journal of Al-Nahrain University.,13(4):15-22; 2010.

[16] Shayma, A. Sh., "Preparation and spectral broperties of mixed-ligand complexes of $\mathrm{VO}(\mathrm{II}), \mathrm{Ni}(\mathrm{II}), \mathrm{Zn}(\mathrm{II}), \mathrm{Pd}(\mathrm{II}), \mathrm{Cd}(\mathrm{II})$ and $\mathrm{Pb}(\mathrm{II})$ with dimethylglyoxime and $\mathrm{N}$ acetylglycine"; E-Journal Chem., 7 (4):1598-1604; 2010.

الخلاصة

تم تحضير الليكاند الجديد 1-(2،2-نثائي سايكلوهكسيل

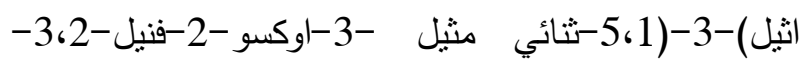

ثنائي هيدرو -1-بايروزول-4-ايل ايمينو) ايندولين-2-2-اون

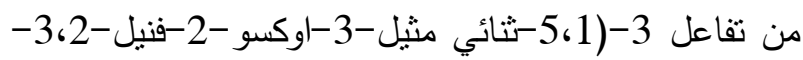

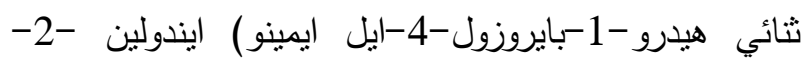

اون مع ثثائي سايكلو هكسيل امين. استعمل اللكياند لتحضير

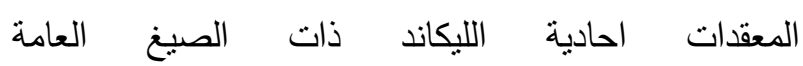

[ $\left[\mathrm{M}^{\mathrm{III}}(\mathrm{L}) \mathrm{Cl}_{3}\right]$ والـ $\left[\mathrm{VO}^{\mathrm{II}}(\mathrm{L})\left(\mathrm{SO}_{4}\right)\right]$

والحديد ثلاثي التكافؤ M

والمنغنيز ثنائي التكافؤ. شخصت المركبات المحضرة لتحديد

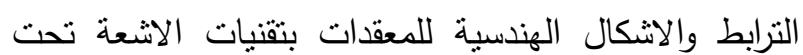


الحمراء، الاثعة فوق البنفسجية -المرئية، طيف الكتلة،

والتحليل الدقيق للعناصر، قياس محتوى الكلور، محتوى

المعدن، التوصيلية المولارية الكهربائية والحساسية

المغناطيسية. أظهرت الدراسة بهذه التقنيات الثكل ثماني

السطوح لمعقدي الكروم والحديد ثناثي التكافؤ ورباعي

السطوح لكل من المنغنيز والكوبلت وهرم مربع القاعدة لمعقد

الفناديل وان نسبة المعدن: الليكاند (1:1). درست المركبات

المحضرة نظريا ببرنامج الهايير كيم الثامن لتحديد حرارة

التكوين وطاقة الترابط والطاقة الكلية وعزم ثثائي القطب

بدرجة حرارة 298 كلفن وبالحالة الغازية لتحديد الاشكال

الهندسية الاكثر استقراراً ثناثية الابعاد واطوال الاواصر . 